\title{
The Status of Coral Reefs in the Remote Region of Andavadoaka, Southwest Madagascar
}

\author{
Nadon M.-O., Griffiths D., Doherty E. and Harris A. \\ Blue Ventures Conservation, 52 Avenue Road, London, N65DR, UK
}

\begin{abstract}
Keywords: Coral reefs, Fringing reefs, patch reefs, sea urchin, reef fisheries, Andavadoaka, Madagascar
\end{abstract}

\begin{abstract}
Three reef systems (fringing, barrier and patch reefs) were surveyed in the region of Andavadoaka, southwest Madagascar. Patch reefs had the highest coral cover and highest density of coral recruits ( $\sim 5 \%$ and $1.8 \mathrm{~m}^{-2}$ recruits), followed by barrier reefs ( $\sim 12 \%$ and 1.3 $\mathrm{m}^{-2}$ recruits) and fringing reefs ( $\sim 8 \%$ and $0.8 \mathrm{~m}^{-2}$ recruits). Sea urchin assemblages varied greatly between reef systems, with fringing reefs being dominated by Echinothrix sp., barrier reefs by the rock-boring sea urchin Echinostrephus molaris and patch reefs by Diadema sp. On all reef types, algae grazing sea urchin densities were six times lower then on overfished reefs elsewhere. The density of commercial invertebrates (e.g., sea cucumbers) did not differ significantly between the relatively unexploited patch reefs versus barrier and fringing reefs, which suggests that these are not yet over-fished in the region. Coral reef fish assemblages were significantly different on each reef system. Reef fish densities were high on both patch and barrier reefs $\left(\sim 170\right.$ per $\left.100 \mathrm{~m}^{2}\right)$ compared to fringing reefs $\left(\sim 90\right.$ per $\left.100 \mathrm{~m}^{2}\right)$. These reefs are not directly threatened by terrigenous sedimentation, which is considered to be one of the principle causes of reef degradation elsewhere in southwest Madagascar's extensive reef system; instead, it is over-fishing that appears to be the main threat to their existence.
\end{abstract}

\section{INTRODUCTION}

The terrestrial environment of Madagascar has for many years been the focus of national and international conservation efforts owing to the vulnerability of its abundant endemic flora and fauna. As a consequence, its extensive marine ecosystems - encompassing coral reefs, mangroves and seagrass beds - have been relatively ignored (Cooke et al. 2000). A recent spur of interest in marine ecosystems has shed light on the poor and fragmented state of the current scientific knowledge of the country's marine environment (Gabrié et al. 2000). Past research on coastal ecosystems in Madagascar has focused on a few regions, such as around Toliara in the southwest (Pichon 1971), Nosy Be in the northwest (McKenna and Allen 2003) and around the Masoala Peninsula in the northeast (McClanahan and Obura 1998). Much of the coastline remains scientifically unknown to researchers and government officials.

Of the main marine ecosystems present in southwest Madagascar, coral reefs are by far the richest and most diverse habitat with an estimated 6000 reef-associated species, including 752 fish species and 340 coral species (McKenna and Allen 2003). The three main threats currently affecting the country's coral reefs are global warming, excessive sedimentation and over-fishing (Cooke et al. 2000). Abnormally warm surface waters, related to a strong ENSO event, affected the region particularly strongly in 1998 and caused widespread coral bleaching in Madagascar (McClanahan and Obura 1998). Terrigenous sedimentation, due to poor agricultural practices such as large-scale deforestation, has caused considerable damage to coral reefs located near large river mouths, such as the Onilahy and Manombo rivers in the southwest part of the country (Gabrié et al. 2000). Finally, 
the number of traditional Malagasy fishermen and boats has increased by a factor of five in the las two decades leading to the over-exploitation of marine resources, especially near urban centers such as Toliara (Gabrié et al. 2000). Fortunately, a significant proportion of the region's coastline remains sparsely populated and distant from river mouths, such as around the coastal village of Andavadoaka in the southwest. Most of the reefs in this region are believed to be in pristine condition. The aim of this article is to give a detailed baseline description of the current state of the coral reefs of Andavadoaka.

The surveys focused on three ecologically or economically important components of the reefs: substrate composition, macro-invertebrates and fishes. These three components are closely interrelated and drastic changes in any of them can severely perturb an entire reef system (Hughes 1994). For example, sea urchin grazing on turf and macro-algae help maintain live coral cover by freeing up bare substrate and limiting alga overgrowth (Hughes et al. 1999). However, important sea urchin populations can cause significant reef erosion, but are usually kept in check by predators, such as triggerfish (CarreiroSilva and McClanahan 2001). Fish communities are in turn affected by the state of their home reefs, relying on coral for protection and nutrition, among other benefits (McClanahan 1994). Finally, local communities depend heavily on coral reef fish and macro-invertebrates for sustenance, making these the most likely components to be first affected by overfishing. Variations in the levels of these two components would thus serve as an early sign of decline in the general health of the Andavadoaka coral reefs.

\section{METHODS}

\section{Study site}

The research site is located in southwest Madagascar near the remote fishing community of Andavadoaka which lies approximately $150 \mathrm{~km}$ north of the regional capital of Toliara and $50 \mathrm{~km}$ south of Morombe $\left(43^{\circ} 13^{\prime} 30 \mathrm{E}, 22^{\circ} 04^{\prime} 22 \mathrm{~S}\right)$. The area is characterized by two distinct fringing and barrier reef systems separated by a $5 \mathrm{~km}$ wide passage or channel in which are situated several patch reefs (Fig. 1). There are no large river outlets within $100 \mathrm{~km}$ of Andavadoaka and preliminary studies suggest terrigenous sediment levels, particularly after storm events, are much lower than for reef systems near the Onilahy and Manombo rivers (D. Griffiths, pers. obs).

The only fishing communities present in the region are Andavadoaka (pop. 1200), Ampasilava (pop. 600) and a small settlement on the island of Nosy Hao (pop. 50). These communities are almost entirely composed of Vezo fishermen. Fishing is carried out using pirogues (small sailing canoes) or walking, limiting most fishing effort to the nearby reef systems, with fishing at deeper, offshore sites only possible during favourable sea conditions. The main exploited organisms are finfish (e.g., Lethrinidae, Serranidae, Scombridae, Lutjanidae), the octopus Octopus cyanea, squid and lobsters.

\section{Survey methods}

Coral reef monitoring was carried out by SCUBA diving from September 2004 to June 2005 at 10 survey sites ( 3 fringing reef sites, 4 barrier reef sites and 3 patch reef sites; Fig. 1) using a combination of marine biologists and trained, non-specialist, volunteers. To record the composition of the substrate, Linear Point Intercept transects or LPI (see Nadon and Stirling 2006) were deployed at each site between 8 and $15 \mathrm{~m}$ depths, along permanent transects delineated by iron stakes. Each transect was $10 \mathrm{~m}$ in length and the uppermost substrate type directly below every $20 \mathrm{~cm}$ marker was recorded, giving 50 sub-sample points per transect. Substrate types were classified in the following categories: hard coral, turf algae (thin algal filaments $<1 \mathrm{~cm}$ long), macroalgae, soft coral, crustose coralline algae, cyanobacteria, sand, bleached coral and other invertebrates (e.g., zoanthids, tunicates, sponges, etc.). A minimum of 6 permanent transects was put in place at each survey site (up to 10 transects). The density of ecologically and commercially important invertebrates was recorded over a $2 \mathrm{~m}$ wide belt along each $10 \mathrm{~m}$ long permanent transect by a second observer using the same tape measure as for PITs. The invertebrates recorded were: four groups of sea urchins (Diadema sp., Echinothrix sp.,

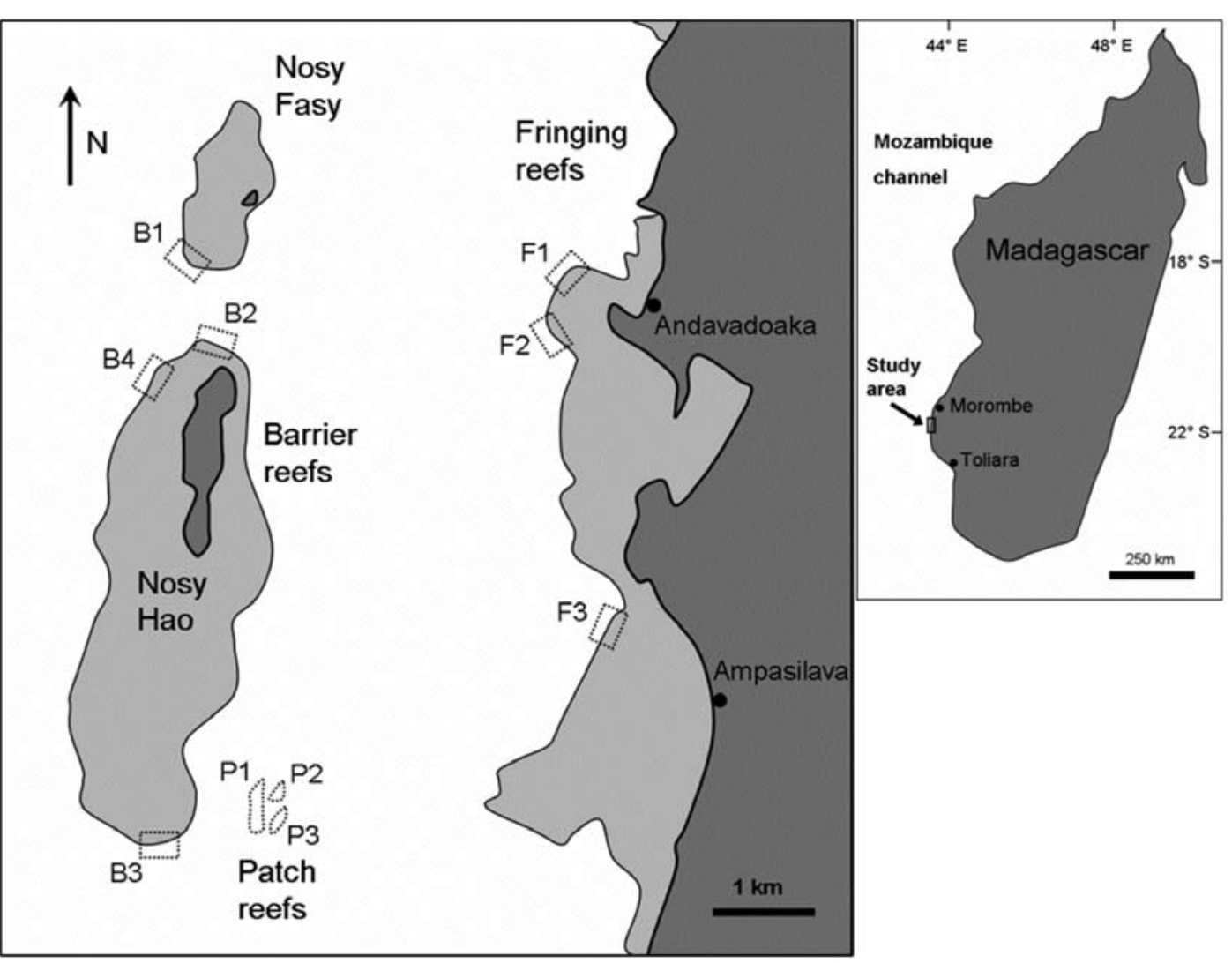

Fig. 1. The three reef systems of the Andavadoaka region (fringing, barrier and patch reefs) with the 10 sampling sites

Echinometra mathaei (Blainville), Echinostrephus molaris (Blainville), triton shell gastropods, crownof-thorns starfish, giant clams and sea cucumbers. The number of coral recruits (diameter $<5 \mathrm{~cm}$ ) was also recorded during these surveys.

The density and taxonomic composition of coral reef fishes were surveyed along belt transects at each site. Belt transects were carried out by deploying a $20 \mathrm{~m}$ long transect line following the contour of a reef at two different depths (side and top of a reef) and waiting for 5 minutes to compensate for the disturbance caused by the divers. Two observers then swam along the transect at a speed of about $4 \mathrm{~m}$ per minute recording fish numbers in an area extending $2.5 \mathrm{~m}$ on both sides of the line and $5 \mathrm{~m}$ above the line ( $5 \mathrm{~m} \times 5 \mathrm{~m} \times 20 \mathrm{~m}$ ). All fish encountered within a transect (excluding cryptic species) were recorded to family level and, if observers were sufficiently trained, to species level.
In order to participate in sampling, all observers were required to accurately identify the species or families (as appropriate depending on the intended level of taxonomic accuracy) of individuals from a list of the 150 most common fishes found in the region.

The aim of this report being to describe the reefs around Andavadoaka at a regional level, most figures and data analyses were made at the scale of the three reef systems (fringing, barrier, and patch reefs). Analysis of Variance (ANOVA) coupled with least significant difference (LSD) pairwise comparisons were used to assess the differences between the three reef systems. ANOVA were used after verification of the basic assumptions behind this procedure. The SYSTAT statistical software was used for these analyses. The PRIMER software was used for multidimensional scaling (MDS) analysis of fish populations. 


\section{RESULTS}

Detailed results of the surveys are presented in the appendix section (Appendix A to D), including the details of the ANOVA procedure (Appendix E).

\section{Composition of the benthos}

Coral cover varied significantly between the three types of reef studied (fringing, barrier and patch

reefs; ANOVA, df=2, 247, F=109, p<0.0001). Patch reefs had significantly higher hard coral cover (42 $\% \pm 2 \mathrm{SE})$ than barrier reefs $(14 \% \pm 1 \mathrm{SE}$; LSD pairwise, $\mathrm{p}<0.0001)$ and fringing reefs $(8 \% \pm 1$ SE; LSD pairwise, $\mathrm{p}<0.0001$ ). Coral cover was significantly higher on barrier reefs than on fringing reefs (LSD pairwise, $\mathrm{p}=0.04$ ). The $\mathrm{P} 1$ and $\mathrm{P} 2$ patch reefs were the sites with the highest coral cover in the region with around $50 \%$ of the substrate covered by live coral (Fig. 2a). Similarly to coral cover, the

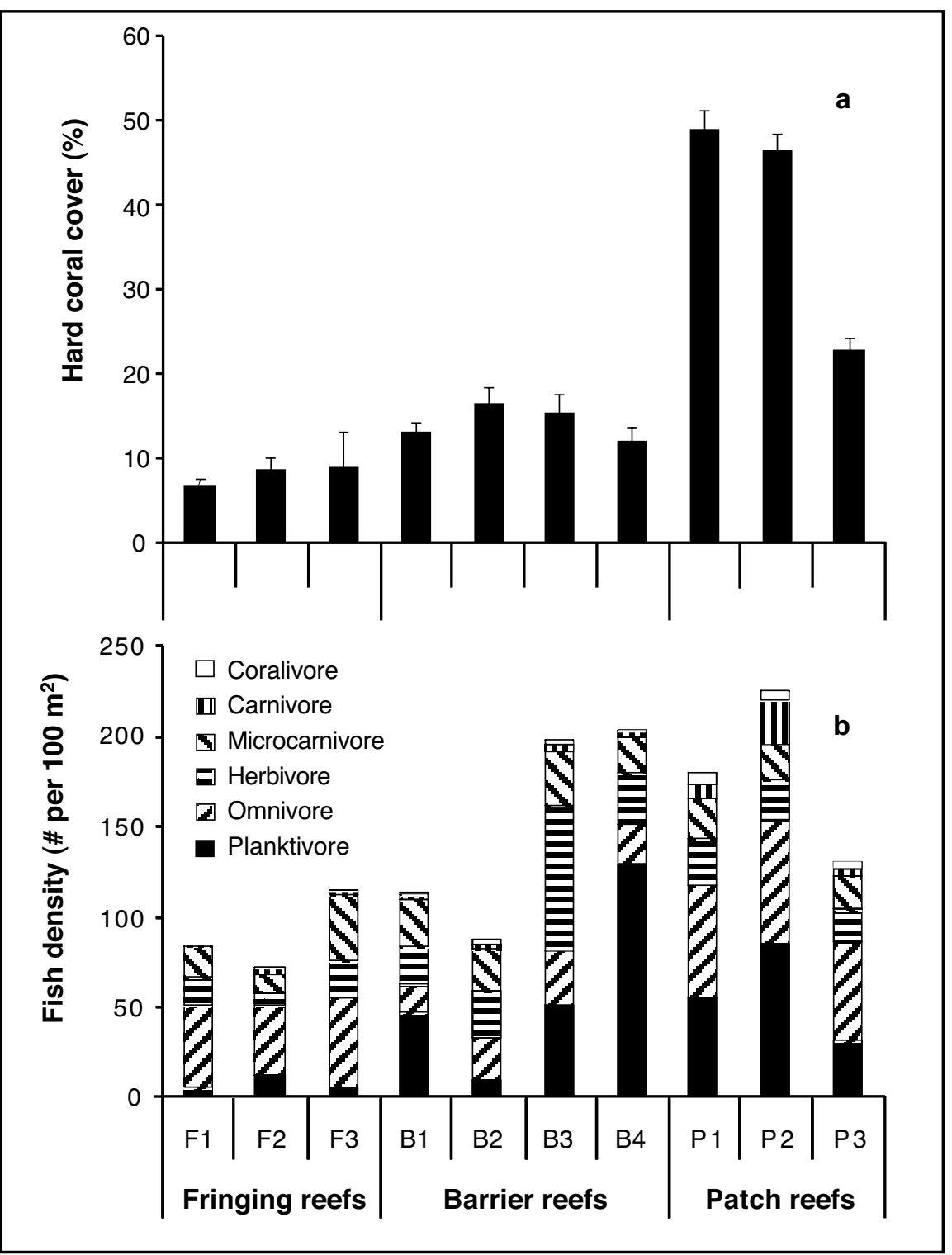

Fig. 2. (a) Percent hard coral cover at various sites around Andavadoaka (mean \pm SE) and (b) average coral reef fish abundance at all survey sites classified by trophic guild density of coral recruits differed markedly between reef types (ANOVA, $\mathrm{df}=2,129, \mathrm{~F}=7.53, \mathrm{p}=0.001$ ). Recruits were in greater abundance on patch reefs $\left(\sim 1.8\right.$ recruits $\left.\mathrm{m}^{-2}\right)$, compared to barrier reefs $(\sim 1.3$ recruits $\mathrm{m}^{-2}$; LSD pairwise, $\left.\mathrm{p}=0.03\right)$ and fringing reefs $\left(\sim 0.8\right.$ recruits $\mathrm{m}^{-2} ;$ LSD pairwise, $\left.\mathrm{p}<0.0001\right)$. The densities of recruits between fringing and barrier reefs were not statistically different (LSD pairwise, $\mathrm{p}=0.07$ ). Filamentous turf algae and macroalgae covered about $60 \%$ of the available substrate on fringing and barrier reefs, but only 30 $\%$ of the substrate on patch reefs. On all reef types, the remaining substrate cover consisted of crustose coralline algae $(\sim 10 \%)$, soft coral $(\sim 5 \%)$ and small patches of cyanobacteria $(\sim 2 \%)$. No significant occurrence of coral bleaching has been observed since monitoring began in the region in 2003.

Sea urchin populations varied markedly between the three types of reef. The rock-boring sea urchin Echinostrephus molaris was significantly more abundant on barrier reefs (mean of 1000 individuals per ha) than on the two other types of reef (ANOVA, df=2, 275, F=10.2, p<0.0001; Fig. 3). Echinothrix individuals were more common on

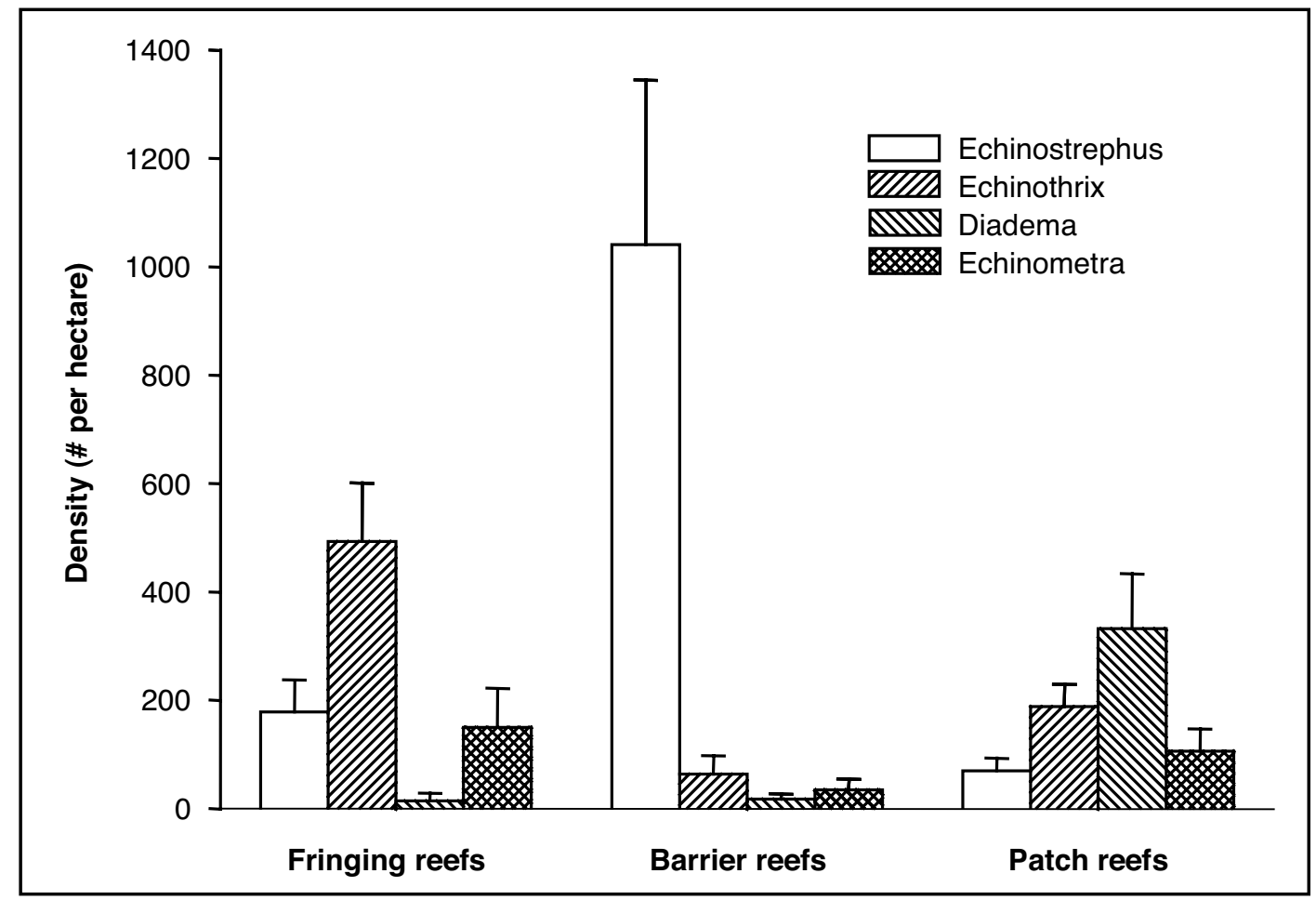

Fig. 3. Sea urchin densities on the three reef systems (mean \pm SE)

fringing reefs than on either patch or barrier reefs (ANOVA, df $=2,275, \mathrm{~F}=11.3, \mathrm{p}<0.001$ ). Finally, patch reefs had a significant presence of Diadema (ANOVA, $\mathrm{df}=2,275, \mathrm{~F}=6.1, \mathrm{p}=0.003$; Fig. 3 ) compared to the other types of reef. In general, fringing and patch reefs had the greatest number of algae grazing sea urchins (Diadema, Echinometra and Echinothrix) with around 600 individuals per ha, versus only 120 individuals per ha on barrier reefs. The three groups of commercial invertebrates surveyed in this study did not differ significantly between the three reef types (ANOVA, $d f=2$, $191, \mathrm{p}>0.10$ for sea cucumbers, triton shells and giant clams). Although these differences were not statistically significant, giant clams and triton shells were encountered more commonly on barrier reefs (Fig. 4). On all types of reef, sea cucumber density was on average 72 individuals per ha; giant clam density 57 individuals per ha and, finally, triton shell density was 21 individuals per ha. The crown-ofthorns starfish (Acanthaster planci L.), although rarely encountered, was in greater abundance on fringing reefs (50 individuals per ha) than on either patch reefs (5 individuals per ha) or barrier reefs 


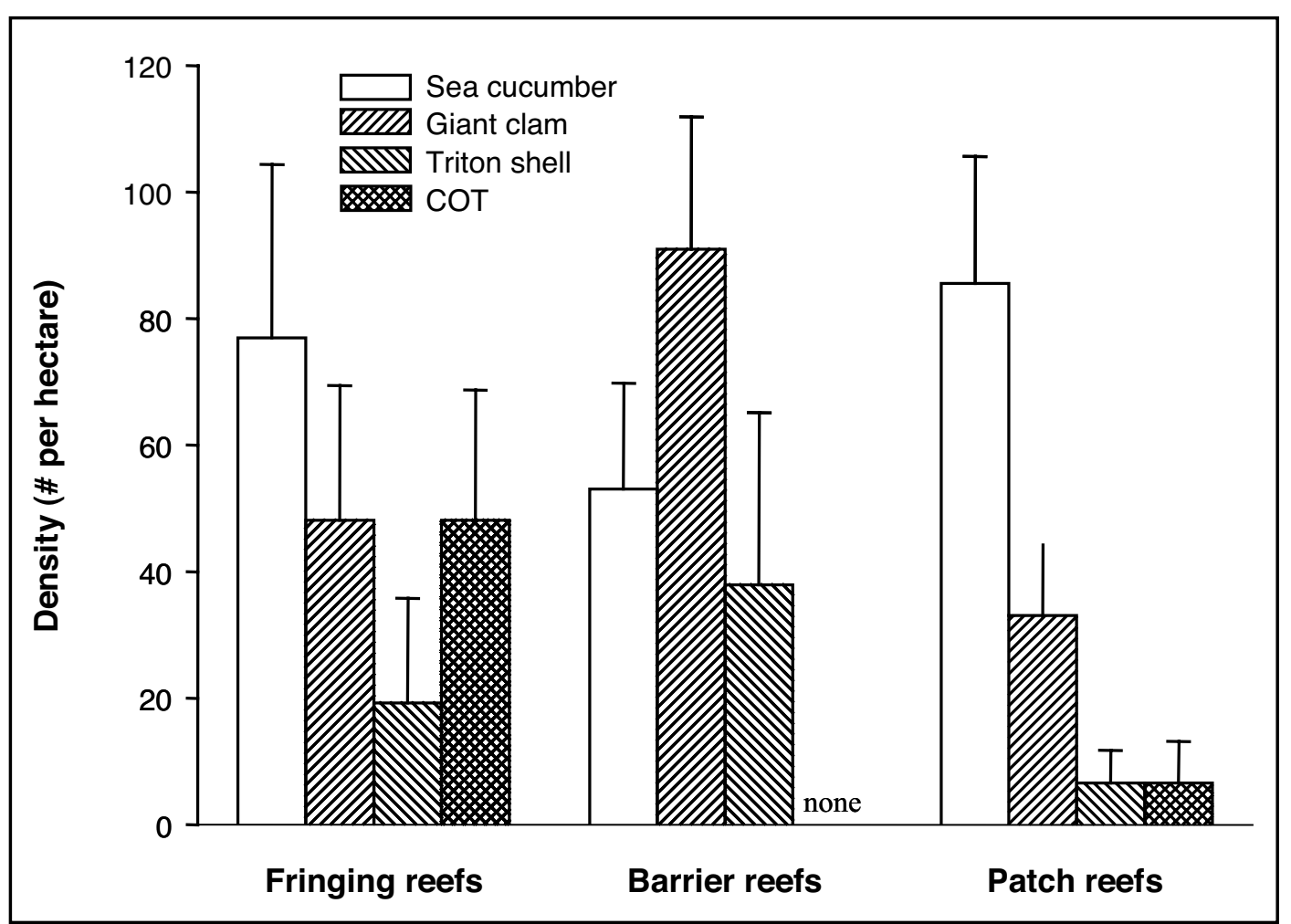

Fig. 4. Density of rare and commercially important invertebrates (mean $\pm \mathrm{SE}$ ). COT stands for crown-of-thorns starfish

(never encountered; ANOVA, $\mathrm{df}=2,191, \mathrm{p}=0.005$ Fig. 4). There was no difference in Acanthaster abundance between barrier and patch reefs (LSD pairwise, $\mathrm{p}=0.89$ ).

\section{Coral reef fish}

Coral reef fishes formed three distinct species assemblages on fringing, barrier and patch reefs when analyzed in a multi-dimensional scaling (MDS) plot using the PRIMER software (Fig. 5; ANOSIM, $\mathrm{R}=0.31, \mathrm{p}=0.03$ ). Patch reefs had a greater diversity of fish assemblages, followed by barrier reefs and fringing reefs (Fig. 5). The family richness (average number of fish families encountered per transect) differed significantly between reef types (ANOVA, $\mathrm{df}=2,184, \mathrm{~F}=14.8$, $\mathrm{P}<0.0001)$. Family richness between patch and barrier reefs was not statistically different with on average 10 fish families encountered per transect (LSD pairwise, $\mathrm{p}=0.45$ ). Family richness was significantly less on fringing reefs compared to the two other types of reef with only 7 families per transect on average (LSD pairwise, $p<0.0001$ for both barrier and patch reefs compared to fringing reefs). There were no statistically relevant differences between the three types of reef in species richness per transect (average of 12 species per transect). There was no significant difference in Shannon diversity indexes $\left(\mathrm{H}^{\prime}\right)$ between reef types at either the family or species level (ANOVA, $\mathrm{p}=0.11$ for family $\mathrm{H}^{`}$ and $\mathrm{p}=0.19$ for species $\mathrm{H}^{`}$ ).

Reef fish abundance was significantly different between reef types (ANOVA, $\mathrm{df}=2,184, \mathrm{~F}=4.1$, $\mathrm{p}=0.02)$. There were twice as many fish on barrier reefs (155 fish per transect) and patch reefs (180 per transect; Fig. 2b). LSD pairwise comparisons were significant between patch and fringing reefs $(p=0.005)$ and between barrier and fringing reefs $(\mathrm{p}=0.05)$. There was no significant difference in fish abundance between patch and barrier reefs (LSD pairwise, $p=0.46$ ). These differences are due to a greater number of both planktivores (e.g., fusiliers fish per transect) than on fringing reefs (80 fish

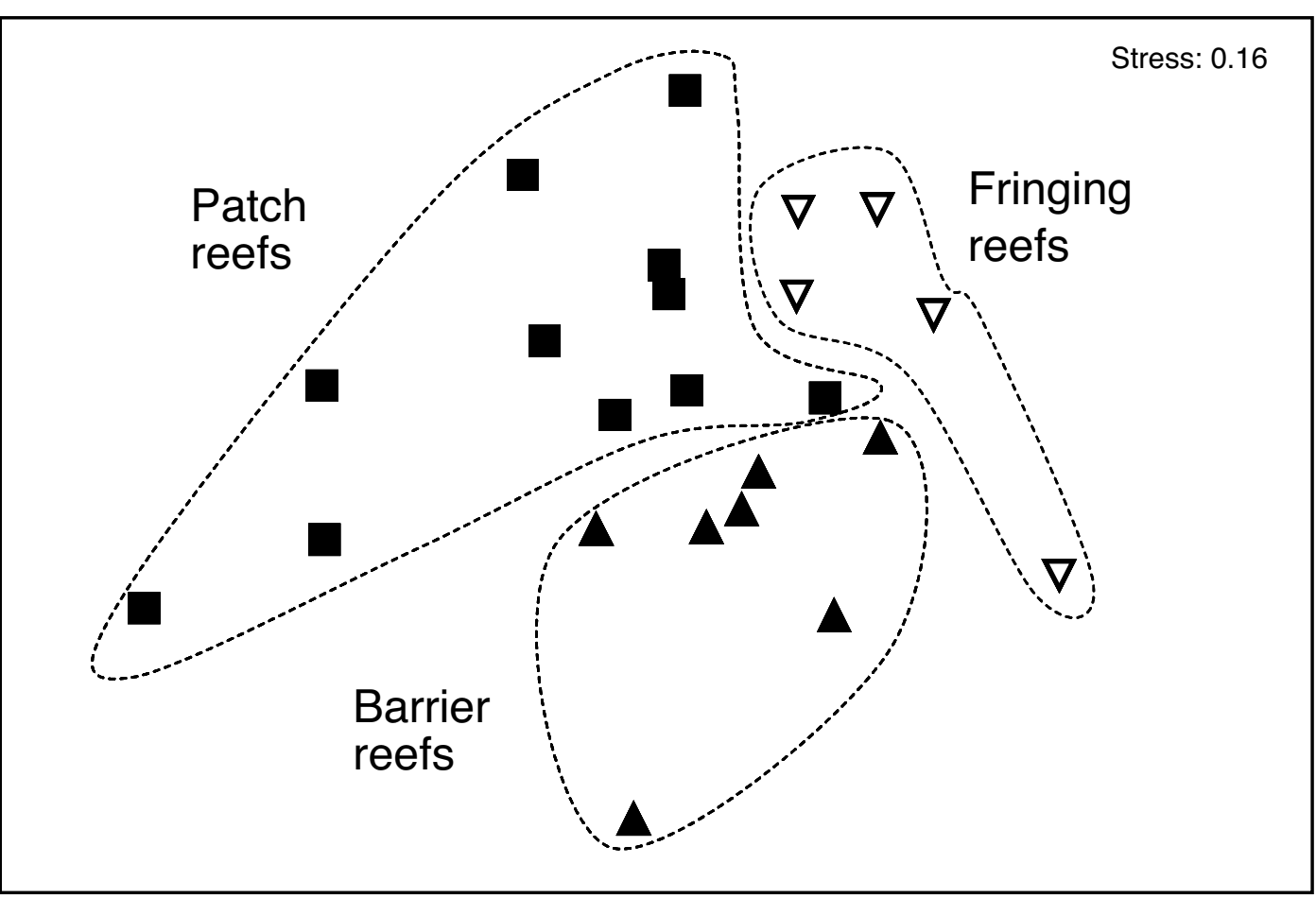

Fig. 5. MDS plot of fish assemblage composition from various sites, sampled at different occasions. Points close to one another have similar reef fish populations

and sweepers) and omnivores (e.g., triggerfish and pufferfish) on these types of reef (Fig. 2b). There were also significantly more coralivores (e.g. butterflyfish) on reefs with higher coral cover (linear regression, $\mathrm{df}=1,8, \mathrm{~F}=58.6, \mathrm{R}^{2}=0.88, \mathrm{p}<0.0001$ ).

\section{DISCUSSION}

The reefs around Andavadoaka are in conditions ranging from moderate (e.g., significant coral cover and fish abundance, but not at pristine level) to excellent (e.g., near pristine level). On almost al aspects, patch reefs are in the healthiest condition, followed by barrier reefs and, finally, by fringing reefs.

The patch reefs found near the southern edge of the Nosy Hao reef flat are by far the healthiest coral reefs in the region with about $45 \%$ coral cover, with some exceptional sites approaching $70 \%$ coral cover (e.g., P1 south). These reefs compare with the healthiest coral habitats found in other parts of Madagascar such as in the northwes ( $70 \%$ coral cover; McKenna and Allen 2003) an around Nosy Be ( $50 \%$ coral cover; Webster and McMahon 2002). They also compare favourably with the healthiest reefs found in Ifaty $(\sim 40 \%)$ and Belo-sur-Mer ( $\sim 55 \%$ coral cover; Ahamada et al. 2002). Another high coral cover ( $33 \%)$ patch reef was recently discovered between the islands of Nosy Hao and Nosy Fasy, and dozens of isolated and deeper patch reefs are found a few kilometres to the south, in front of the Bay des Assassins. Barrier and fringing reefs, occupy a much larger area than patch reefs, but have far less coral cover $(\sim 12 \%$ and $\sim 8 \%$, respectively). Similarly, the densities of coral recruits are also lower on both barrier and fringing reefs compared with patch reefs, which suggests that these two reef areas will probably not achieve coral covers similar to patch reefs in the near future. The higher coral covers found on patch reefs and to a lesser extent barrier reefs are probably due to their generally greater depth, which reduces their susceptibility to coral bleaching from abnormally warm surface waters, and the reduced fishing effort on them. 
The over harvesting of certain species of fish can drastically increase the density of key invertebrates, typically sea urchins, by removing their predators (Roberts 1995 and McClanahan 1998). Sea urchins are important reef eroders and their number can strongly affect coral reef structure (Carreiro-Silva and McClanahan 2001). Algae grazing sea urchins (i.e. all genera studied except Echinostrephus) can also benefit coral reefs by removing significant amount of algae which can potentially compete against coral for space and lead to algae dominated states (Hughes 1994 Hughes et al. 1999). Conversely, sea urchins such as Echinometra mathaie and Echinothrix spp. can accelerate erosion of the reef through continuous grazing activity (Bak 1990). In the Andavadoaka region, sea urchin assemblages vary greatly between the three types of reef, with fringing reefs being dominated by large individuals from the Echinothrix genus, barrier reefs being strongly dominated by small, rock-boring Echinostrephus molaris urchins, and patch reefs being dominated, to a lesser extent, by individuals from the Diadema genus. The overall density of the three large algae grazing sea urchins found in the Andavadoaka region ( 400 urchin per ha) is similar to those encountered on protected sites in Kenya and Tanzania ( 430 urchin per ha) and 6 times lower then on unprotected, overfished sites in the same region ( 2500 per ha; McClanahan et al. 1999). The extreme density of sea urchin encountered on unprotected sites in Kenya and Tanzania was explained by the excessive removal of their predators (e.g., triggerfish) by fishing. The relatively low densities of sea urchin on the three reef systems in Andavadoaka thus suggests that urchin populations are appropriately regulated by a sufficient abundance of key predators and is an indication that these reefs are not over-fished.

There is no significant difference between barrier, fringing and patch reefs in the abundance of the three commercial invertebrates sampled (sea cucumbers, triton shells, and giant clams). Patch reefs have a very low fishing pressure and should have almost natural abundances of these invertebrates; the fact that barrier and fringing reefs have similar densities suggests that these species are not yet over fished on these reefs. The overall density of Acanthaster planci in the region ( 15 per ha) can be considered high compared to the typically low concentrations found elsewhere in the Indian Ocean $(\sim 0.2$ per ha; McClanahan 2000). This is no serious cause for concern since Acanthaster densities are not currently excessive, even on fringing reefs, and triton shell gastropods, its natural predator, are still commonly found on all types of reef. Furthermore, major crown-of-thorns outbreaks are rare in the western Indian Ocean and have never been recorded in Madagascar (McClanahan 2000).

Unsurprisingly, the high coral cover patch reefs also harbour the highest fish densities, including the highest density of coralivorous butterflyfish (Chaetodontidae) which, as was previously shown, are a reliable indicator of reef health in the region. The densities on patch and barrier reefs compare very favourably with those measured on both protected and unprotected coral reefs in Kenya and Tanzania, which were similar to the low levels found on Andavadoaka's fringing reefs at around 90 fish per $100 \mathrm{~m}^{2}$ (McClanahan et al. 1999). This suggests that the heavier fishing pressure over barrier reefs has not yet significantly affected their reef fish population.

The main manageable threat to the reefs of Andavadoaka in the foreseeable future is over fishing from the traditional Vezo fishermen in the communities of Andavadoaka, Ampasilava and Nosy Hao. Threats from foreign or domestic longline and live-aquarium fisheries are absent. By most accounts, the reefs in the region appear to be relatively unaffected by over-fishing. However, the population of Andavadoaka, now at 1000 with 350 fishermen (60\% of the active population), is growing at a high rate of $4 \%$ a year (FID 2003) and signs of overfishing will no doubt start appearing in the next few decades, as in the rest of the region (Laroche et al. 1997) and most parts of the world. These reefs will continue to be closely monitored in the foreseeable future by Blue Ventures Conservation in partnership with the Wildlife Conservation Society and the Malagasy government.

Acknowledgements -For their help in the field with sampling design, the establishment of monitoring stations, volunteer training and data collection thank you to Tom Hardy, Amelia Curd, Katie Yewdall, Kit Gillibrand, Bic Manahira, Victor Bonito, Henk van Rein and Josephine Langley. In the UK office thank you to Tom Savage, Anju Nihilani and Hugo Selbie for their hard work in enabling the field research to continue. Thank you to Dr. Man Wa Rabenevanana and Dr. Mara Edouard Remanevy at the Institut Halieutique et des Sciences Marines, Dr. Simon Harding at the Wildlife Conservatio Society and Andrew Cooke for all technical assistance and continued support in country. Specia thanks to Richard Nimmo for ensuring all logistical requirements were always taken care of. Finally, many thanks to every volunteer ever to work with Blue Ventures in Andavadoaka, without whom none of the information we now have of this unique region could have been collected.

\section{REFERENCES}

Ahamada, S., Bigot, L., Bijoux, J., Maharavo, J., Meunier, S., Moyne-Picard, M. \& Paupiah, N. (2002) Status of coral reefs in the south west Indian Ocean island node: Comoros, Madagas Mauritius, Reunion and Seychelles, Im: Wilkinson, Mauritius, Reunion and Seychelles. In: Wilkinson, (he world. Australian Institute of Marine Science, Townsville,
pp 79-100. pp 79-100

ak, R. P. M. (1990) Patterns of echinoid bioerosio in two Pacific coral reef lagoons. Mar. Ecol. Prog. Ser. 66: 267-272.

Carreiro-Silva, M. \& McClanahan, T.R. (2001) Echinoid bioerosion and herbivory on Kenyan coral reefs: the role of protection from fishing. J. Exp. Mar. Biol. Ecol. 262: 133-153.

Cooke, A., Ratomahenina, O. \& Ranaivosoin, E. (2000) Madagascar. In: Sheppard, C.R.C. (ed.) Seas of the Millennium. Elsevier Science press, pp 103-119.

FID (2003) Plan communal de développement: Befandefa. Commune de Befandefa, Madagascar, Toliara.

Gabrié, C., Vasseur, P., Randriamiarana, H., Maharavo, J. \& Mara, E. (2000) The Coral Reefs of Madagascar. In: McClanahan, T., Sheppard, Madagascar. In: McClanahan, T., Sheppard,
C.R.C., Obura, D.O. (eds.) Coral Reefs of the C.R.C., Obura, D.O. (eds.) Coral Reefs of the
Indian Ocean. Oxford University Press, New York.

Hughes, T., Szmant, A.M., Steneck, R., Carpenter, R. \& Miller, S. (1999) Algal blooms on cora reefs: what are the causes? Limnol. Oceanogr. 44: $1583-1586$.

Hughes, T.P. (1994) Catastrophes, phase shifts, and large scale degradation of a Caribbean coral reef. Science. 265: 1547-1551.

Laroche, J., Razanoelisoa, J., Fauroux, E. \& Rabenevanana, M.W. (1997) The reef fisheries surrounding the south-west coastal cities of Madagascar. Fish. Manag. Ecol. 4: 285-299.

McClanahan, T.R. (1994) Kenyan coral reef lagoon fish: effects of fishing, substrate complexity, and sea urchins. Coral Reefs. 13: 231-241.

McClanahan, T.R. (1998) Predation and the distribution and abundance of tropical sea urchin populations. J. Exp. Mar. Biol. Ecol. 221: 231-255.

McClanahan, T. (2000) Coral reef use and conservation. In: McClanahan, T., Sheppard, C.R.C., Obura, D.O. (eds.) Coral reefs of the Indian Ocean. Oxford University press, New York.

McClanahan, T. \& Obura, D.O. (1998) Monitoring, training and assessment of the coral reefs of the Masoala Peninsula. Wildlife Conservation Society report.

McClanahan, T.R., Muthiga, N.A., Kamukuru, A.T., Machano, H. \& Kiambo, R.W. (1999) The effects of marine parks and fishing on coral reefs of of marine parks and fishing on coral reefs o

Hcrion

bivid marine biodiversity assessment of northwest Madagascar. Conservation International report, Washington,
DC. DC

don, M.-O. \& Stirling, G. (2006) Field and simulation analyses of visual methods for sampling coral cover. Coral Reefs. 25: 177-185.

Pichon, M. (1971) Comparative study of the main features of some coral reefs of Madagascar, La Reunion and Mauritius. Symp. Zool. Soc. Lon 28: $185-216$.

Roberts, C. (1995) Effects of fishing on the ecosystem structure of coral reefs. Conserv. Biol. 9: 988995.

Webster, F. J. \& McMahon, K. (2002) An Assessment of Coral Reefs in Northwest Madagascar. In: Obura (eds.) Coral degradation in the Indian Ocean Stat Reart CORDIO, Depe Indian Ocean: Status Report. CORDIO, Department of of Kalmar, Kalmar, Sweden. 
Appendix A. Mean substrate cover ( $\mathrm{SE}$ in parentheses) at all survey sites. $\mathrm{HC}=$ coral cover, $\mathrm{TA}=$ turf algae, $\mathrm{MA}$ = macroalgae, $\mathrm{CA}=$ crustose coralline algae, $\mathrm{SC}=$ soft coral, $\mathrm{CYA}=$ cyanobacteria

\begin{tabular}{lccccccccc}
\hline Reef type & Site & $\mathbf{n}$ & HC & TA & MA & CA & SC & CYA & Others \\
\hline Fringing reefs & F1 & 16 & $6.5(1.1)$ & $46.8(6.3)$ & $30.7(6.0)$ & $5.3(0.9)$ & $4.1(0.9)$ & $0.3(0.2)$ & $2.0(0.5)$ \\
& F2 & 20 & $8.7(1.4)$ & $48.9(5.4)$ & $30.9(4.2)$ & $2.9(0.8)$ & $4.0(1.0)$ & $1.0(0.3)$ & $2.3(0.5)$ \\
& F3 & 10 & $8.8(4.2)$ & $48.2(3.4)$ & $15.2(1.8)$ & $24.6(4.1)$ & $0.6(0.4)$ & $1.2(1.2)$ & $1.2(0.6)$ \\
Barrier reefs & & & & & & & & & \\
& B1 & 20 & $13.1(1.0)$ & $33.4(3.5)$ & $26.2(2.1)$ & $12.1(2.1)$ & $4.3(1.4)$ & $3.9(0.9)$ & $3.3(0.5)$ \\
& B2 & 23 & $16.3(2.0)$ & $31.5(3.6)$ & $36.2(3.6)$ & $7.0(1.8)$ & $2.1(0.7)$ & $1.1(0.3)$ & $2.3(0.8)$ \\
& B3 & 20 & $15.2(2.1)$ & $25.1(3.1)$ & $26.2(3.6)$ & $19.8(2.8)$ & $3.9(0.8)$ & $5.9(1.5)$ & $1.1(0.4)$ \\
& B4 & 20 & $11.8(1.6)$ & $36.2(3.3)$ & $22.1(1.9)$ & $22.9(2.5)$ & $0.7(0.3)$ & $1.1(0.4)$ & $3.1(0.5)$ \\
Patch reefs & & & & & & & & & \\
& P1 & 46 & $49.0(3.0)$ & $24.7(3.4)$ & $5.7(1.0)$ & $11.8(1.5)$ & $4.3(1.0)$ & $0.8(0.3)$ & $3.8(0.8)$ \\
& P2 & 35 & $46.4(2.7)$ & $18.1(2.6)$ & $12.0(1.9)$ & $10.7(1.8)$ & $5.3(1.5)$ & $2.0(0.8)$ & $5.6(1.3)$ \\
& P3 & 40 & $22.7(2.1)$ & $39.8(3.5)$ & $14.8(3.3)$ & $9.9(1.4)$ & $5.1(1.4)$ & $2.8(1.2)$ & $4.7(0.8)$
\end{tabular}

Appendix C. Coral reef fish diversity at all sites measured as richness (\# of taxa per transect) and with the Shannon index $\left(H^{\prime}\right)$. Numbers are averages with SE in parenthesi

\begin{tabular}{|c|c|c|c|c|c|c|}
\hline \multirow[t]{2}{*}{ Reef type } & \multirow[t]{2}{*}{ Sites } & \multirow[t]{2}{*}{$\mathbf{n}$} & \multicolumn{2}{|c|}{ Species level } & \multicolumn{2}{|c|}{ Family level } \\
\hline & & & $\mathbf{S}$ & H' & $\mathbf{S}$ & H' \\
\hline \multirow[t]{3}{*}{ Fringing reefs } & F1 & 6 & $15.2(3.2)$ & $2.2(0.2)$ & $7.8(0.7)$ & $1.4(0.1)$ \\
\hline & $\mathrm{F} 2$ & 20 & $9.2(2.4)$ & $1.4(0.3)$ & $6.3(0.6)$ & $1.2(0.1)$ \\
\hline & F3 & 6 & $10.7(2.5)$ & $1.8(0.2)$ & $8.3(1.0)$ & $1.6(0.2)$ \\
\hline \multirow[t]{3}{*}{ Barrier reefs } & B2 & 21 & $13.5(1.8)$ & $2.1(0.1)$ & $10.0(0.4)$ & $1.8(0.0)$ \\
\hline & B3 & 11 & $13.7(2.2)$ & $1.7(0.2)$ & $10.4(0.9)$ & $1.5(0.2)$ \\
\hline & B4 & 20 & $14.6(0.8)$ & $1.9(0.1)$ & $8.1(0.5)$ & $1.2(0.1)$ \\
\hline \multirow[t]{3}{*}{ Patch reefs } & P1 & 39 & $11.9(1.2)$ & $1.6(0.1)$ & $9.9(0.5)$ & $1.4(0.1)$ \\
\hline & P2 & 29 & $10.1(2.2)$ & $1.6(0.3)$ & $9.6(0.6)$ & $1.4(0.1)$ \\
\hline & P3 & 29 & $11.4(2.9)$ & $1.5(0.3)$ & $10.1(0.4)$ & $1.5(0.1)$ \\
\hline
\end{tabular}

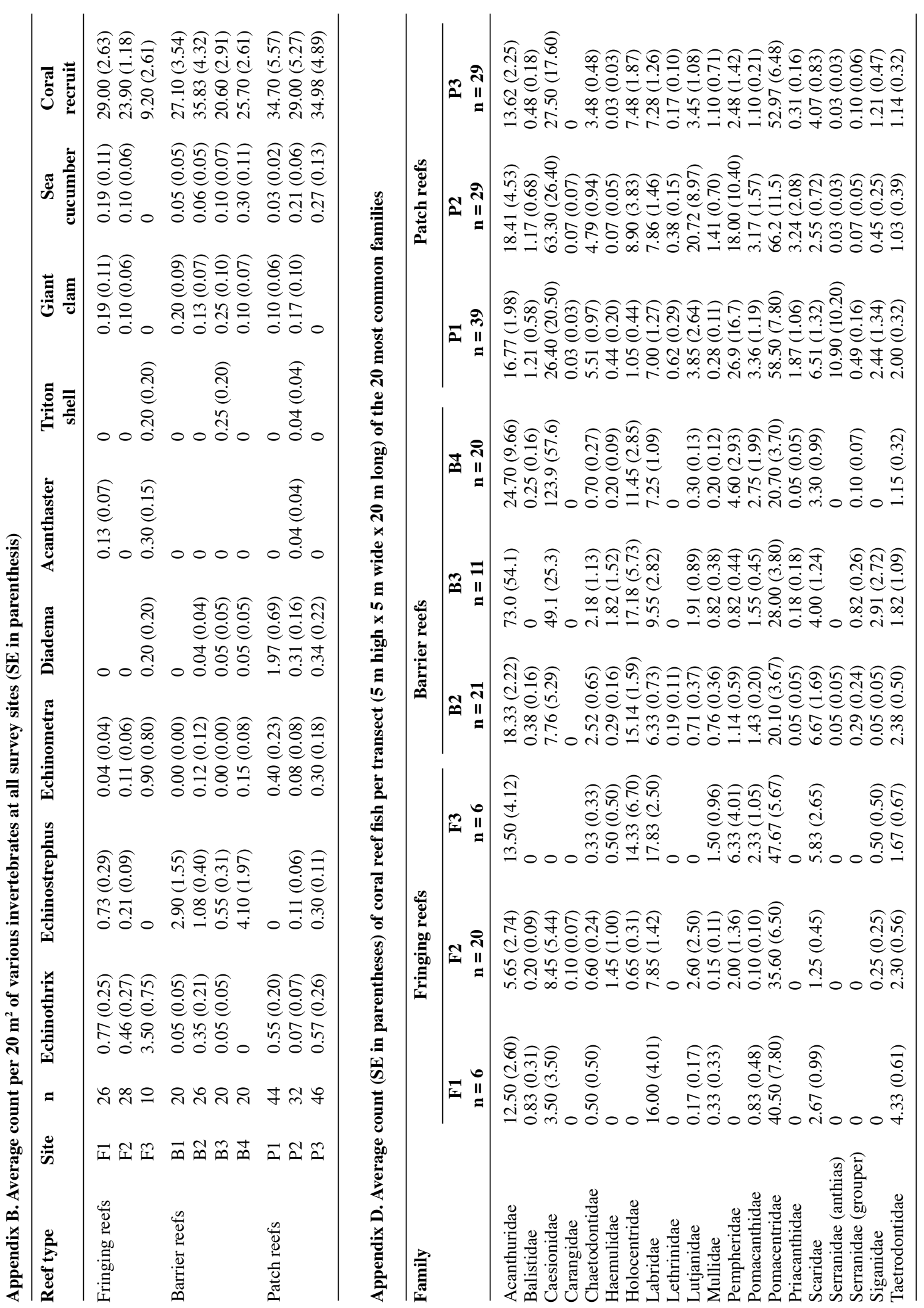


Appendix E. Summary of ANOVAs comparing the three different reef systems. * indicates significant differences at the 0.05 level

\begin{tabular}{|c|c|c|c|c|}
\hline Source & DF & MS & F-ratio & p-value \\
\hline \multicolumn{5}{|c|}{ Substrate composition } \\
\hline \multicolumn{5}{|c|}{ Coral cover } \\
\hline Reef type & 2 & 28885 & 109 & $<0.0001 *$ \\
\hline Error & 247 & 264 & & \\
\hline \multicolumn{5}{|c|}{ Coral recruits } \\
\hline Reef type & 2 & 3385 & 7.53 & $0.001 *$ \\
\hline Error & 129 & 449 & & \\
\hline \multicolumn{5}{|l|}{ Invertebrates } \\
\hline \multicolumn{5}{|c|}{ Echinostrephus molaris } \\
\hline Reef type & 2 & 104 & 10.20 & $<0.0001^{*}$ \\
\hline Error & 275 & 10 & & \\
\hline \multicolumn{5}{|c|}{ Echinothrix sp. } \\
\hline Reef type & 2 & 15 & 11.32 & $<0.0001 *$ \\
\hline Error & 275 & 1.3 & & \\
\hline \multicolumn{5}{|c|}{ Echinometra sp. } \\
\hline Reef type & 2 & 1.1 & 1.41 & 0.247 \\
\hline Error & 275 & 0.7 & & \\
\hline \multicolumn{5}{|c|}{ Diadema sp. } \\
\hline Reef type & 2 & 13.7 & 6.08 & $0.003 *$ \\
\hline Error & 275 & 2.2 & & \\
\hline \multicolumn{5}{|c|}{ Sea cucumber } \\
\hline Reef type & 2 & 0.078 & 0.47 & 0.627 \\
\hline Error & 191 & 0.167 & & \\
\hline \multicolumn{5}{|c|}{ Giant clams } \\
\hline Reef type & 2 & 0.248 & 2.258 & 0.107 \\
\hline Error & 191 & 0.110 & & \\
\hline \multicolumn{5}{|c|}{ Triton shell } \\
\hline Reef type & 2 & 0.060 & 0.62 & 0.541 \\
\hline Error & 191 & 0.113 & & \\
\hline \multicolumn{5}{|c|}{ Acanthaster planci } \\
\hline Reef type & 2 & 0.154 & 5.35 & $0.005^{*}$ \\
\hline Error & 191 & 0.029 & & \\
\hline \multicolumn{5}{|c|}{ Fish } \\
\hline \multicolumn{5}{|c|}{ Richness (family level) } \\
\hline Reef type & 2 & 107 & 14.88 & $<0.0001 *$ \\
\hline Error & 184 & 7.2 & & \\
\hline \multicolumn{5}{|c|}{ Richness (species level) } \\
\hline Reef type & 2 & 72 & 1.81 & 0.169 \\
\hline Error & 89 & 39.7 & & \\
\hline \multicolumn{5}{|l|}{ Density } \\
\hline Reef type & 2 & 130230 & 4.00 & $0.020 *$ \\
\hline Error & 184 & 32505 & & \\
\hline
\end{tabular}

